
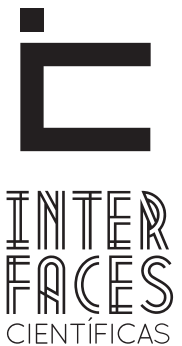

DIREITO

\title{
MODERNIDADE, RAZÃO PENAL, CONSTITUIÇÃO E ARBíTRIO
}

Patrícia Verônica Nunes Carvalho Sobral de Souza ${ }^{1}$

\section{RESUMO}

Toda sociedade para harmonizar os indivíduos que a compõe tem de ser submetida a sanções. Vários pensadores analisaram as razões e formas de penalidades existentes e passaram a estudar concepções mais pedagógicas da pena. A modernidade trouxe ao modelo estatal a ideia do contrato social (razão e arbítrio) para aquele indivíduo dotado de liberdade. Com a criação do Estado surge uma nova ideologia fundada na Constituição, na separação dos poderes e nos direitos individuais. A Constituição de 1988 assegurou princípios que compreendem o Direito Penal, contempla as ideias de cunho garantista, em que não é razoável abolir o Direito penal, nem abolir as prisões, mas garantir a sua utilização mínima, com base na legalidade e demais garantias acobertadas pela Carta Magna de 1988.

\section{PALAVRAS-CHAVES}

Modernidade; constitucionalismo; razão penal; arbítrio; garantismo penal.

\section{ABSTRACT}

Every society to harmonize the individuals that compose it must be subjected to sanctions. Several thinkers have analyzed the reasons and forms of punishments and started studying pedagogical penalty conceptions. Modernity has brought to the state model the idea of the social contract (reason and will) for that individual endowed with freedom. With the creation of the State comes a new ideology based on the Constitution, the separation of powers and individual rights. The Constitution of 1988 ensured principles that comprise the Criminal Law contemplates the guarantism ideas, it is not reasonable to abolish criminal law, nor to abolish prisons, but ensure its minimal use, based on legal and other guarantees covered up by Magna Carta of 1988.

\section{KEYWORDS}

Modernity. Constitutionalism. Criminal Reason. Will. Criminal Guarantism. 


\section{RESUMEN}

Toda sociedad para armonizar los individuos que lo componen debe ser objeto de sanciones. Varios pensadores han analizado las razones y formas de castigos y se comenzó a estudiar las concepciones pedagógicas. La modernidad ha traído al modelo de Estado la idea del contrato social (razón y voluntad) para ese individuo dotado de libertad. Con la creación del Estado, vino una nueva ideología basada en la Constitución, la separación de poderes y los derechos individuales. La Constitución de 1988 aseguró principios que componen el Código Penal y contem- pla las ideas de la naturaleza garantista, en la que no es razonable la abolición de la ley penal, ni abolir las prisiones, sino garantizar su uso mínimo, basado en las garantías legales y demás respaldos de la Magna Carta de 1988.

\section{PALABRAS CLAVE}

Modernidad. Constitucionalismo. Razón Penal. La Agencia. Garantismo Penal.

\section{INTRODUÇ̄̃̃O}

O homem é um ser social e toda sociedade para harmonizar os indivíduos que a compõe tem de ser submetida a sanções pela conduta considerada socialmente imprópria. Como consequência, existem penas desde os tempos imemoriais e primitivos como uma forma de promover a convivência social e, com a evolução da sociedade, elas foram evoluindo e sendo reformuladas.

Existiram, ao longo dos séculos, os mais diversos tipos de penas: as consideradas cruéis como a de morte, açoites ou mutilação, castigos corporais e outros tipos de repressão penal; e a decorrente da perda do patrimônio, também comum e alcançava os descendentes do infrator, indo, assim, além da pessoa do condenado e sendo, portanto, sem o caráter personalíssimo que tem hoje. No Brasil, por exemplo, Tiradentes foi condenado pelo crime de Lesa Majestade: sua pena foi cruel tanto para ele como para seus descendentes.

Vários pensadores analisaram as razões e formas de penalidades existentes, bem como as concepções mais pedagógicas da pena. A título de registro histó- rico, e de forma ilustrativa, o sofista Protágoras, na Grécia Clássica, examinou as formas de penalização, e considerou que a finalidade do castigo é a correção do homem infrator, além de entender que a virtude poderia ser ensinada e aprendida, por ser o homem portador de inteligência. Sócrates, por sua vez, opositor ferrenho dos sofistas, considerava que não dependia do esforço humano tornar os homens bons. Aristóteles, mais adiante, ainda na Grécia, defendia que a pena e o crime deveriam estar interligados à procura de uma justa medida e que o justo estaria na medida certa e, portanto, defendia a ponderação, também denominada de "virtude aristotélica".

Mais adiante, faz-se necessário mencionar a dualidade existente na Idade Média entre a religião e o Estado (pecado e crime) e, que, por consequência, a pena visava punir o aspecto moral da conduta, ou seja, o pecado. Eram aplicadas penas de forma cruel e desumana aos plebeus e penas de forma branda (multas) aos nobres, cuja responsabilização penal era objetiva e não a pessoal como vigora hoje no Brasil. 
A modernidade, no entanto, trouxe diversas transformações atreladas ao modelo estatal em que a razão e o arbítrio apresentaram uma subida valoração e destaque. 0 homem, produtor desta modernidade, deixou de ser conduzido por uma divindade dando lugar ao pensamento racional. Há uma transição do teocentrismo para o antropocentrismo e o homem natural passa, neste contexto, para a condição de indivíduo. Com isso, as formas de punição foram revistas: o positivismo e a legalidade, consubstanciados numa Carta Constitucional que salvaguarda os direitos fundamentais de cunho principiológico e penal, foram essenciais para assegurar as garantias do indivíduo e do cidadão, evitando-se as penas cruéis, degradantes e reduzindo-se o nível de arbitrariedade, com base numa razão proporcional que está intimamente ligada ao garantismo penal. Tal garantismo não significa abolicionismo, nem uma liberdade selvagem, mas, sim, uma adequação do Poder punitivo do Estado em relação à liberdade do indivíduo.

Tendo em vista os aspectos já descritos, o presente trabalho possui grande relevância para os interessados na área do direito penal e tem por objetivo a

\section{DIREITO PENAL NO CONTEXTO DA MODERNIDADE}

Com o advento do Iluminismo e com a Revolução Francesa, os intelectuais da época se mobilizaram no sentido de promover uma reforma social, mormente quanto aos abusos da Igreja e do Estado. Tal movimento trouxe novas ideias que repercutiram tanto na Europa como nos Estados Unidos, em Declarações como a da Independência dos Estados Unidos, na Francesa dos Direitos do Homem e do Cidadão, e no surgimento de um Direito Penal mais humanitário, liberal, laico, longe das amarras do catolicismo. Nomes importantes como Espinosa, Locke, Montesquieu e Voltaire muito contribuíram para a eclosão desta grande transformação política e social. abordagem conceitual da penalização ao indivíduo, advinda com a modernidade, contida na Constituição Federal de 1988, e seus reflexos quanto ao viés sociológico e quanto ao arbítrio, sem olvidar do garantismo que envolve toda a temática.

Nesse pensamento, o Direito Penal é fruto de diversas transformações filosóficas, jurídicas e sociais, e será passível de outras, conforme o caráter histórico de sua evolução social. Seria razoável abolir o Direito penal, utilizar a sua aplicação mínima e extinguir as prisões? Haverá uma resposta satisfatória quanto à forma de punição do Estado em relação aos fatos puníveis, sem se chegar ao arbítrio? Como se falar em arbítrio diante de uma realidade democrática insculpida em uma Constituição Cidadã?

Para responder a tais indagações e alcançar os objetivos propostos acima, o procedimento metodológico utilizado foi o explanatório, a partir das leituras realizadas, através de um referencial teórico obtido em levantamento bibliográfico, como livros, artigos e legislações, fundado na utilização dos conhecimentos acumulados dos autores e pesquisadores da temática.

O Marquês de Beccaria escreve "Dos Delitos e das Penas", obra que se perpetuou até os dias hodiernos por criticar toda uma ordem de atrocidades das penas aplicadas até então, como: tortura, pena de morte e infamantes e toda a sorte de desigualdades. Na verdade, ele advogava a legalidade e a proporcionalidade das penas aos delitos, afirmando que o direito de punir deveria consubstanciar uma utilidade social, a humanização das penas e a publicidade dos processos. Defendia ainda a separação entre os poderes judiciário e legislativo, como garantia de uma maior independência entre os poderes, posto que quem cria a lei não deve também julgar e vice-versa. 
Nesse contexto, o indivíduo passa a ser figura preponderante em relação ao Estado, pois este nada mais é do que um instrumento para o indivíduo que o compõe. Novos caminhos estavam sendo abertos para garantir igualdade e justiça à humanidade, a exemplo da pena que passa a ter um caráter utilitarista, ou seja, ela deve ser aplicada levando em consideração o bem de todos (coletivo), e deve prevenir para que o agente não volte a cometer novos delitos, numa forma de corrigir ou melhorar o transgressor. Tal entendimento foi defendido por Jeremy Bentham e Stuart Mill.

A Contrario sensu, Kant e Hegel $^{1}$ defendiam não ser concebível punir um homem como método para procurar outro fim, ou seja, o fim da criminalidade. Para o primeiro, o criminoso precisava reconhecer o quanto vale aquilo que fez; a pena seria absoluta (não estaria ligada a nada); e defendia suas ideias com base no imperativo categórico em que a pena seria aplicada como consequência da lei ter sido violada e não apenas por imposição da mesma. Para Hegel, a pena é castigo e tem função reativa, metodológica e dialética (negação tese - síntese - antítese); relaciona pena e crime; o crime nega o direito e a pena nega o crime e restaura o direito.

O princípio da taxatividade ganha destaque na fase do Iluminismo, isto é, só haverá crime quando a conduta estiver emoldurada dentro do tipo penal, sendo que este tipo deve estar disposto em lei (nullum crimen sine previa legem). ${ }^{2}$

1 Defensores da Teoria retributiva ou absoluta da pena em que a pena é a resposta ao autor do delito pela ação delitiva cometida por este.

2 Necessário falar, neste contexto, da relevância da escola clássica para o direito penal, visto que foram sistematizados os institutos penais da imputação da pena, da culpabilidade, dentre outros que são utilizados na atualidade. 0 crime e o criminoso não eram os focos principais desta escola. O livre arbítrio foi rejeitado, mas defendiam um homem livre e determinista (determinismo biológico e determinismo social). Os maiores expoentes foram Carrara, que desenvolveu um programa de direito criminal, com pressupostos do crime e da culpabilidade do agente, e Feuerbach que criou o Código Penal da Baviera (1813), dando suporte ao princípio da legalidade (nullum crimen sine lege).
A Teoria Preventiva, mais necessária para o reforço da temática em estudo, abordava a pena como um projeto de transformar e melhorar o indivíduo. Tem-se: a prevenção especial que se dirige àquele indivíduo infrator; a prevenção geral que se dirige a toda a comunidade e pode ser negativa e positiva, sendo a primeira como elemento de ameaça e coerção psicológica, e a segunda consistindo no resgate do sentimento de realidade do direito, sendo um instrumento de reafirmação do direito, e foi defendida posteriormente por Günther Jakobs da escola funcionalista radical.

Há de se mencionar ainda o funcionalismo moderado defendido por Roxim, que tinha o direito penal como fim eminentemente preventivo.

A escola cartográfica afirmava que o crime deve ser analisado por meio de estatísticas, em razão de ser um fenômeno concreto. Neste mesmo período surgiram como expoentes Lombroso, Ferri e Garófalo, defensores da escola positivista. Tal corrente via o homem como um ser pré-determinado, e considerava o criminoso como um doente que precisava ser tratado (aplicação da medida de segurança). Acreditavam, também, que o homem não age por livre arbítrio, mas que há na sua ação a influência de fatores endógenos (hereditários) e exógenos (sociais).

É cediço que não há consenso sobre a questão da pena. Trata-se de um tema aberto. A dogmática jurídica não consegue definir a pena como prevenção ou castigo. Há ambiguidade de posicionamentos. Enfim, a pena não dá para ser explicada apenas pelas Teorias Jurídicas. A questão central da pena é a impunidade. 


\section{RAZÃO PENAL E O DIREITO DE PUNIR DO ESTADO}

A concepção moderna trouxe em seu bojo a ideia do contrato social para aquele indivíduo, ora dotado de razão e liberdade. Nesta toada, surge o Estado para resolver problemas sociais, criar e aplicar sanções.

É certo que o ser humano, em sua condição mais pretérita, no estado mais natural e primitivo, vivia sem o aparato de qualquer aparelho ou aparelhamento que the desse garantia ou segurança nas suas relações interpessoais. Tudo que emergia com o condão de the impor dificuldade era resolvido por meio da força bruta, e pela sobreposição do mais forte e submissão do mais fraco. Nessa fase evolutiva, o ser humano estava à mercê do arbítrio alheio, mas gozava de plena liberdade, ainda que ameaçada a todo e qualquer tempo. Eram tempos de beligerância.

0 modo e as premissas que guiam a percepção da Relação Estatal com o indivíduo vêm sendo repensadas desde a modernidade (que surge com a razão humana). Na segunda metade do Séc. XVIII - Revolução Francesa x Revolução Americana - surgiram as premissas limitadoras do Estado (quanto ao Direito Penal).

Visando maiores garantias e a consecução de fins comuns, o ser humano despoja-se de parte da sua individualidade, de sua liberdade, para criar um ente chamado Estado, aquele que seria o depositário da confiança de todos e que, em nome da coletividade, perseguiria o bem comum e livraria a todos das usurpações e submissão arbitrária do homem pelo homem, pelo instrumento da força.

Firmou-se, pois, o Contrato Social, teorizado por Jean-Jacques Rousseau, saindo o homem do seu estado natural para o convencional. Ele defendia a ideia de democracia direta em que a razão é o guia do homem. Para ele, o homem abdica de sua liberdade e contrata a criação do Estado.
Historicamente, o primeiro Código Penal surgiu em 1603, com o Livro V das Ordenações Filipinas. 0 Direito Penal, de forma mais ampla, aparece quando se percebe a diferença entre Direito Natural e o Direito Positivo, e ele é formado por um conjunto de normas jurídicas que regulam o poder punitivo do Estado, levando em consideração os fatos puníveis e as medidas aplicáveis aos infratores. Cabe ao Estado, como mantenedor da ordem e paz da coletividade, descrever tais condutas como infrações penais (tipificação); cominar, em consequência, as respectivas sanções, e estabelecer todas as regras necessárias à sua aplicação.

Desta feita, o Estado chamou para si a responsabilidade sobre o direito de punir como cumprimento de uma vontade geral, a fim de que ninguém ficasse ameaçado pelo desarrazoado arbítrio alheio, mas que a liberdade de todos estivesse confiada, de forma indistinta, impessoal, ao Estado. Seria a pena, pois, o meio de impedir que o infrator cause novos danos aos concidadãos e o meio de represália (exemplo) para outros que porventura queiram delinquir.

Diante de tais constatações, o Estado não consegue dar respostas satisfatórias a essas mudanças estruturais, sejam de cunhos positivistas ou sociológicos. Como ensina Barroso (2009, p. 274), o mundo perpassou por diversas escolas de pensamento, a saber: formalismo, reação antiformalista, positivismo e de volta aos valores.

O formalismo caracterizou-se pela concepção do mecanicismo do Direito, cuja atividade interpretativa alijava-se da função crítica. Nele, a crítica dava lugar à subsunção do fato à norma, como fruto de pura submissão legal, posto que a norma derivava da vontade geral expressada pelos seus legítimos representantes. 
Neste modelo, o exegeta encontrava-se restrito a uma interpretação literal do texto legal, adequando, de forma aritmética, o fato à norma, ficando o julgador aos lineares ditames da lei fria.

Em contraponto, a reação antiformalista visava a quebra dessa ordem seca, retilínea e formatada para dar lugar a uma interpretação que alcançasse a finalidade da ordem jurídica, como defendido por Rudolph Von Ihering, para o qual o Direito deveria servir para os fins sociais, antes mesmo que aos conceitos e às formas.

0 positivismo vem com a ideia de separação do que é Direito e do que é Moral, chegando, inclusive, a negar a existência do próprio direito natural como um Direito, levando a crer que Direito apenas era o positivado.

Nessa linha, desenvolveu-se o pensamento no sentido de que o juiz, ao proferir sua decisão, assim fazia por um ato de escolha dentre as possibilidades que a norma the oferece, não estando mecanizado a uma interpretação estritamente linear do texto legal, de forma aritmética, como propunha, v. g., o formalismo.

Expressando essa ideia, Hans Kelsen, na Teoria Pura do Direito, defendeu que o ato de jurisdizer não seria apenas um ato de conhecimento, de simples aplicação do conteúdo legal ao fato concreto, mas um somatório do ato de conhecimento com o de vontade, que se revela na escolha de uma das inúmeras possibilidades de aplicação da norma ao fato concreto que se lhe põe para julgamento.

No que diz respeito à volta aos valores, esta começa a ganhar corpo com a derrocada do positivismo jurídico e da supremacia da lei, após os incidentes do holocausto, do fascismo e do nazismo.

0 pós-positivismo, por essas razões, traz os valores de volta ao centro das discussões jurídicas, daí decorrendo a Declaração Universal dos Direitos Humanos, disseminando valores como o da dignidade da pessoa humana, da 'normatividade' dos princípios, da argumentação jurídica e da racionalidade prática.

Não se pode hoje pensar, pois, que por ser o Direito uma atribuição Estatal, toda e qualquer lei, desde que tenha vigência e eficácia, poderá indistintamente valer dentro do ordenamento jurídico, mormente quando afronta absurdamente direitos que são inerentes à condição humana de existência, sem os quais os indivíduos tornam-se coisa, um mero instrumento de realização do Poder pelo Poder, sofrendo as peias de um Estado que não representa a vontade dos administrados, dos verdadeiros titulares do Poder, mas, em contrassenso, utiliza-se do meio idôneo (processo legislativo) para a criação e validação de atos 'legalmente possíveis' conquanto órfãos de dignidade.

$\mathrm{Na}$ verdade, os limites do direito de punir encontram amparo em alguns princípios que vingaram durante a Modernidade. De forma perfunctória, podem-se apresentar três princípios garantistas que delimitam o poder punitivo do Estado. 0 primeiro, o Princípio da Estrita Legalidade, seria a única forma de prevenir e perseguir delitos racionalmente, indicando preventivamente os tipos penais em sede de ameaça legal, ou seja, só podem ser prevenidas e combatidas as ações previstas e não aquelas imprevistas, mesmo que danosas. 0 segundo, o Princípio da Materialidade dos Delitos, onde seria possível prevenir delitos somente quando as ações fossem expressadas por comportamentos exteriores, e não em estados de ânimos interiores, ou situações subjetivas, como maldade, periculosidade, infidelidade, imoralidade, anormalidade psicofísica ou similares. E o terceiro, o Princípio da Culpabilidade e Responsabilidade Pessoal, onde as ações passíveis de prevenção por meio da ameaça penal são somente aquelas culpáveis e voluntárias, e não as inculpáveis decorrentes da involuntariedade, de caso fortuito, da força maior ou ato de terceiros; a culpabilidade, nesse contexto, trabalha com a ideia de dolo ou culpa, vedando a responsabilidade penal 
objetiva. A Constituição Federal ao estabelecer, em seu artigo $5^{\circ} \mathrm{XLV}$ e XLVI, que nenhuma pena passará da pessoa do condenado, consagrou o princípio da pessoalidade que impede a punição por fato alheio, como pode ocorrer em outros ramos do direito.

\section{CONTEXTO CONSTITUCIONAL E O GARANTISMO PENAL}

Vê-se que com a criação do Estado Moderno surge uma nova ideologia fundada na Constituição, na separação dos poderes e nos direitos individuais. A Constituição de 1988 assegurou princípios que estão compreendidos no Direito Penal e incorpora valores superiores que envolvem a comunidade, expressando ideais de liberdade e democracia que compõem o Estado.

Alvissareiro é o chamado Estado Constitucional de Direito, vez que impõe submissão constitucional ao princípio da legalidade, fazendo com que o ordenamento jurídico tenha como condição de validade a própria Constituição, que as leis e outras normas juridicamente postas perpassem pelo filtro constitucional de validação.

No que tange à normatividade da Constituição, tem-se que as normas constitucionais são disposições que possuem força de normas jurídicas, ou poder normatizante, sob elas recaindo a possibilidade de impingir o regramento ali posto a todas as demais regras que compõem o conjunto normativo, como condição de validade destas últimas.

Sob o ponto de vista material, dois são os assuntos que merecem destaque: a incorporação explícita de valores e opções políticas nos textos constitucionais, com maior atenção para a dignidade da pessoa humana e os direitos fundamentais; e a expansão dos con-
Tais parâmetros, de cunho principiológicos, são essenciais para se evitar o arbítrio por parte do Estado, posto que os atos e as práticas da Administração devem estar em compasso com os desígnios de uma sociedade, decorrentes de um contrato social objeto da criação do Estado.

flitos específicos e gerais entre as opções normativas e filosóficas encontradas no sistema constitucional vigente.

Já a superioridade da Constituição sobre o restante da ordem jurídica deflui dos sistemas que adotam o modelo de Constituição rígida, nos quais a modificação do conteúdo constitucional está adstrito a regras específicas a processo legislativo especial e agravado por maiores imposições.

No modelo de rigidez constitucional, há distinção entre as leis constitucionais, que são superiores, e as leis comuns, inferiores, entre as quais há uma relação de hierarquia, com destaque para as constitucionais, que se apresentam no topo hierárquico normativo.

É de se ver que esses valores estão espalhados na Carta Magna de 1988, desde o seu preâmbulo, dos quais se destacam: assegurar o exercício dos direitos sociais e individuais, a liberdade, a segurança, o bem-estar, o desenvolvimento, a igualdade e a justiça como valores supremos de uma sociedade fraterna, pluralista e sem preconceitos, fundada na harmonia social e comprometida, na ordem interna e internacional, com a solução pacífica das controvérsias; a dignidade da pessoa humana; prevalência dos direitos humanos; pluralismo político; construir uma sociedade livre, justa e solidária; erradicar a pobreza e a marginalização e reduzir as desigualdades sociais e regionais; repúdio 
ao terrorismo e ao racismo; direitos sociais à educação, saúde, alimentação, trabalho, moradia, lazer, segurança, previdência social, proteção à maternidade e à infância e assistência aos desamparados.

0 direito penal caracteriza-se pela mínima intervenção e pela máxima garantia dos direitos individuais fundamentais, tendo por função defender os direitos humanos positivados nas Constituições e no Direito Internacional. 0 Estado de Direito na democracia é essencialmente garantístico. Neste contexto, de acordo com Carvalho (1999, p. 752), o garantismo penal assume papel fundamental: ao passo que sustenta o direito penal, leva as garantias positivadas pelo constitucionalismo ao alcance dos indivíduos.

Toda vez que surge uma nova tipificação delituosa pelo legislador, impõe-se um ônus à coletividade, em razão da possibilidade de punição sobre todos os cidadãos que vierem a incorrer neste novo tipo penal.

$\mathrm{Na}$ atual conjuntura do direito penal, constata-se a dificuldade de encontrar um meio termo entre a tutela da segurança social com as garantias individuais fundamentais da pessoa humana.

Pode-se dizer que, nesta linha, a essencialidade da presença do Princípio da Proporcionalidade ou Razoabilidade, assim também chamado, são conceitos que foram atualizados ao longo do tempo e adquiriram uma nova roupagem. Aristóteles, em Ética a Nicômaco, dizia na teoria do justo meio que o bem é procurar a excelência moral. Alia-se a ideia da proporção, sob o ponto de vista do direito penal, aos tempos modernos no século XVIII. Tal princípio está contido na Carta Cidadã de 1988 de forma implícita, precipuamente no seu preâmbulo. Como ilustração ao excesso legal, vê-se uso de algemas para os delinquentes que não conferem periculosidade alguma à sociedade.

De acordo com Carvalho Filho (2012, p. 41), o grande fundamento do princípio da proporcionalidade é evitar o excesso de poder, e o fim a que se destina é exatamente o de conter atos, decisões e condutas de agentes públicos que ultrapassem os limites adequados. Com fundamento na doutrina alemã, o autor descreve que a proporcionalidade deve compreender: Adequação - o meio empregado na atuação deve ser compatível com o fim colimado; Exigibilidade - o meio escolhido é o que causa o menor prejuízo possível para os indivíduos; e Razoabilidade - as vantagens devem superar as desvantagens.

Segundo Zaffaroni (2004, p. 172), “o princípio da humanidade das penas é o que dita a inconstitucionalidade de qualquer pena ou consequência do delito que crie um impedimento físico permanente [...] como também qualquer consequência indelével do delito".

É de se levar em consideração os axiomas contidos na Constituição Federal de 1988 "Nulum crimen, nulla pena sine legis" (não há crime sem lei anterior que o defina). Deve-se previamente indagar se realmente houve conduta? Se a mesma é típica? É lícita? 0 autor é culpado? A instauração da ideia de responsabilidade pessoal - o Princípio da Personalidade Penal - foi de suma importância, pois este princípio até então era desconhecido. A pena não pode ir além da pessoa do infrator. Todos os enunciados protetivos, de cunho constitucional, relativos ao direito penal, estão, em sua maioria, insculpidos no art. $5^{\circ}$ da Carta Maior.

Valioso ressaltar que a lei regulará a individualização da pena em três fases: cominação, o trabalho que individualiza a pena; aplicação, o juiz levará em consideração para sua aplicação à ação praticada pelo agente contrária às determinações da norma, cabendo-lhe a censura, sem olvidar da participação da vítima; e a execução, que é regida pela lei de execução penal.

$\mathrm{Na}$ Teoria das Penas Legais - tratado das provas judiciais - o juiz lança mão de outros expedientes quando a pena é demasiada. A pena deve ser a expressão do fato social, sendo analisadas as causas de aumento e diminuição na sua cominação. 
O juiz pode valer-se de mecanismos para legitimar e justificar a pena, tais como o princípio da culpabilidade, que condiciona a intervenção estatal ao resultado danoso e o princípio da subjetivação, pelo qual se observa elementos subjetivos na ilicitude, este presente na Lei maior (art. 5² LVIII, CF/88).

O Estado não pode timbrar o cidadão de culpado enquanto estiver vinculado a um processo. Quanto à passagem de um estado de inocência para o de culpa deve se observar: o Princípio da Personalidade da Pena (art. $5^{\circ}$, XLV, da CF); o Princípio da Responsabilidade sobre o fato; e o Princípio da Punibilidade.

A formação do homem da lei é demasiadamente legalista. Pode-se imaginar enganosamente que a regra é o centro do direito. Na realidade, existem concepções de cunho social e filosófico que influenciam a construção moral do homem.

A Teoria do Garantismo Penal, desenvolvida por Luigi Ferrajoli, na sua obra Direito e Razão: Teoria do Garantismo Penal, pressupõe um modelo normativo do direito no qual há um sistema de limites à autoridade punitiva com o fito de conferir maior garantia de liberdade.

Essa Teoria tem por base uma antítese: de um lado as liberdades individuais e de outro o poder punitivo do Estado. Nesse campo, Ferrajoli defende que o poder punitivo do Estado deve ser minimizado, ao ponto sustentável, e maximizadas as liberdades dos cidadãos. Garantismo é, portanto, o meio termo que se alcança com o Direito Penal diminuído, através de uma política criminal minimalista, o que gera, na visão do jus filósofo, o equilíbrio.

Primeiramente, há que se ter em mente que garantias são direitos, privilégios, isenções e imunidades que a Constituição confere aos cidadãos. 0 Garantismo é um modelo de política criminal que representa uma releitura do Direito Constitucional, como obviedade de uma Democracia Constitucional, que garante a todos os direitos fundamentais, sejam eles de liberdade, sociais ou políticos, com sua incidência, necessariamente, no Direito Penal, de onde surgiu e se desenvolveu. Por ser justamente um modelo normativo, o Garantismo pode e deve ser extensivo a todos direitos fundamentais, seja no âmbito social, privado ou público, como meio de proteção.

Grande contribuição para se entender o mecanismo dos métodos punitivos imputados pelo poder estatal, foi dado por Foucault no sentido da pena não ter apenas teor repressivo, mas também da adoção de outras táticas mais brandas, voltadas para a humanização das penas, imputadas de acordo com uma regulamentação legal, precisa e indistinta para todos.

Desta feita, Luigi Ferrajoli centra o Garantismo com base no desequilíbrio entre a liberdade humana e o poder estatal. A normatização do Estado deve se voltar para o alcance do direito penal mínimo, em que as liberdades são aumentadas e o poder é reduzido ao mínimo necessário à manutenção da ordem pública. Não se quer, com isso, pregar o estado criminalmente abolicionista, sem regras, nem mesmo o Estado Antiliberal, extremamente punitivo. Garantismo é um modelo de direito amparado em uma liberdade regrada.

Assim, o Estado não pode mais ser visto como aquele ente sedento por punição, mas, sim, aquele que está limitado na sua condição punitiva justamente pelo Garantismo. Isso representa uma nova roupagem ao velho Estado, que um dia foi pensado e defendido por Thomas Hobbes como sendo o Leviatã, uma autoridade máxima, inquestionável, que todos deveriam obediência. Já em Beccaria, como citado anteriormente, o Estado deveria punir porque o fazia justificado na "necessidade de defender o depósito da salvação pública das usurpações particulares". Ocorre que, em inúmeras vezes, é o Estado que surrupia as mínimas garantias dos cidadãos, sob precisamente essa pífia justificativa de fazer justiça, da prestação da segurança aos administrados, de punir os responsáveis, o que se afigura altamente perigoso, pois se 
esquece de primeiro achar os responsáveis, para depois puni-los. É tamanha a necessidade de punir e mostrar à sociedade que o modelo adotado funciona que o Estado, por vezes, ocupa-se mais com a punição do que com a cognição.

Na visão de Ferrajoli, o Garantismo, advindo do Direito Constitucional moderno, representa uma larga escala de direitos limitativos a todos os tipos de Poder, como sendo um núcleo de proteção conferido aos cidadãos contra os excessos estatais.

Nesse passo, o Garantismo Penal não passa a ser somente uma garantia de liberdade e imunidade contra o arbítrio, mas como uma segurança de verificação da verdade, através do processo de cognição, no qual são veladas todas essas garantias para que se chegue, definitiva e indubitavelmente, à verdade.

Aí é que surge o modelo de Direito Penal mínimo como um modelo garantista, fundado nas balizas do processo de conhecimento, a fim de se ter a garantia da certeza do direito, que não é absoluta, mas que concebe ao Estado, como titular do direito de punir, e ao acusado, como destinatário das garantias, a confiança de que não serão feitas acusações infundadas, acusações imprecisas.

Então, visa o garantismo a certeza nas imputações fáticas que são perpetradas pelo Estado, como deve sê-lo, através de um processo de conhecimento, preservando as garantias do acusado, não utilizando o processo como meio de estigmatizar, de rotular, de punir por punir, de punir porque há que se terem culpados, mas de punir aquele que realmente cometeu o delito, posto da certeza, ainda que relativa, do fato típico configurado e aclarado no devido processo legal de conhecimento.

Isso não quer fazer crer que o modelo Garantista Penal só admita o processamento diante da verdade absoluta, eis que inexistente essa verdade, posto ser sempre relativa, já que sujeita à probabilidade, inclu- sive do erro, o que sempre deve ser considerado pelo Poder Judiciário. 0 erro é imanente à condição humana e a verdade absoluta não.

O que se deseja garantir é a verificação da verdade, da forma mais correta e segura em relação ao processo, daí ser o processo de conhecimento uma marca do Garantismo (cognitivismo processual), a busca da verdade, levando-se em conta a pré-falada relatividade da verdade e a sempre presente possibilidade de erro.

Desta feita, a busca desse Garantismo Penal, segundo Ferrajoli, pode ser alcançada pelo que ele chama de sistema garantista, que se perfaz em dez axiomas ou dez princípios axiológicos fundamentais, como técnicas de minimização do poder institucionalizado, divididos, sinteticamente, em três grupos de garantias, a saber:

Ferrajoli utilizou técnicas de minimização do Poder Institucionalizado do Estado que estão representadas nesses dez axiomas, de garantias relativas à pena, relativas ao fato ou crime e garantias relativas ao processo. No caso das garantias correlatas à pena: Nulla poena sine crimine, não há pena sem a prática do crime, e para que se possa afirmar o cometimento do crime é necessário que esse crime tenha sido efetivamente perpetrado; Nullum crimen sine lege, esse corresponde ao princípio da legalidade e, assim, não há crime sem que haja lei anterior (Princípio de Anterioridade), escrita, estrita e certa; Nulla lex (poenalis) sine necessitate, não há lei penal sem necessidade, ou seja, sem necessidade não se criam leis penais, é o princípio da necessidade ou princípio da intervenção mínima do Direito Penal.

Em se tratando das garantias correlatas ao delito, têm-se: Nulla necessitas sine injuria, ou seja, não há necessidade de aplicação da lei penal sem relevante e concreta (não abstrata) lesão ou perigo de lesão, é o princípio da lesividade, da estrita proteção aos bens jurídicos ou da ofensividade do evento; Nulla injuria 
sine actione, se não há exteriorização da conduta, não há lesão, é o princípio da exteriorização da ação ou, ainda, da materialidade, não se pune sem ação, só por pensamento ou por adoção de mero estilo de vida, e há que se ter a ação exteriorizada; Nulla actio sine culpa ou não há ação típica sem dolo ou culpa, é o princípio da culpabilidade e também da responsabilidade pessoal.

Sobre as garantias correlatas ao processo: Nulla culpa sine judicio ou o princípio da jurisdicionariedade, a culpa há de ser verificada em regular juízo e o reconhecimento de culpa é feito pelo órgão judicial, face, inclusive, o monopólio da jurisdição; Nullum judicium sine accusatione ou a acusação não pode ser feita pelo próprio juiz, é o princípio acusatório, pois o juiz não age de ofício, ou da separação entre o juiz e acusação e, portanto, não pode reconhecer culpa sem ser provocado, e inicialmente o juízo é inerte, não produzindo prova diretamente, mas subsidiariamente; Nulla accusatio sine probatione, ou seja, não há acusação sem o mínimo de prova, pois a acusação é que deve ser provada, não a inocência, é o princípio do ônus da prova (que cabe a quem acusa) ou da verificação; e Nulla probatio sine defensione ou não há prova válida sem contraditório e defesa, é o princípio do contraditório e da ampla defesa.

Como visto, Ferrajoli encadeia os axiomas de forma sucessiva e sistemática para o que ele chama de regras do jogo fundamental do direito penal ou princípios políticos, morais ou naturais de limitação do poder penal "absoluto", que vieram a ser incorporados às constituições e codificações do moderno Estado de direito.
Propõe, assim, de forma lógico-sucessiva, que não há pena sem a prática do crime. E para que haja o crime, há que ter lei anterior tipificando a conduta socialmente repreendida. Deve, pois, a conduta justificar a atividade legislativa, porque sem necessidade não se cria a lei penal. Para que essa lei deva ser aplicada, cogente ser faz a presença concreta de lesão ou, no mínimo, de perigo de lesão. Portanto, sem a exteriorização da conduta, não há lesão, pois não se pune sem ação, só por pensamento, eis que pensamento não traduz concretude.

Esse fato concreto de lesão deve ser imputado a alguém, pessoa determinada, para se apontar o culpado. Mas essa culpa só pode ser apontada pelo juízo, pois compete ao órgão judicial o monopólio da jurisdição, deste modo, só ele pode reconhecer a culpa.

Não obstante a imputação da culpa seja ato judicial, a acusação não pode ser feita pelo próprio juiz, pois ele não age de ofício, visto que juiz é uma coisa e acusação é outra diversa, devendo o juiz ser provocado para tal fim, face a sua inércia.

De outra parte, para se acusar alguém, deve-se ter prova do alegado, já que alegar sem provar é o mesmo que não alegar, competindo ao acusador fazer a prova. Por fim, essa prova, para que seja válida, deve respeitar o contraditório e a ampla defesa, sob pena de invalidade.

Após essa construção lógica, Ferrajoli aponta que esses dez axiomas vão dar corpo, por silogismo, a 45 teoremas que reforçam a tese da utilização prática, e não apenas do “dever-ser”, do Garantismo pelo Estado através dos operadores do direito. 


\section{CONCLUSÃO}

Interessante notar que o próprio idealizador do Garantismo Penal aponta que o Estado será mais ou menos garantista o tanto quanto adotar, com maior ou menor aceitação, a teoria em suas constituições e codificações.

Nesse contexto, o Brasil se encaixa como um modelo de Estado de direito social, pois veda ações estatais que restrinjam a liberdade dos cidadãos [ninguém será obrigado a fazer ou deixar de fazer alguma coisa senão em virtude de lei; ninguém será submetido à tortura nem a tratamento desumano ou degradante...] ao tempo em que garantem prestações positivas por parte desse mesmo Estado [o Estado promoverá, na forma da lei, a defesa do consumidor; o Estado prestará assistência jurídica integral e gratuita aos que comprovarem insuficiência de recursos; são direitos sociais a educação, a saúde, a alimentação, o trabalho, a moradia, o lazer, a segurança, a previdência social, a proteção à maternidade e à infância, a assistência aos desamparados...].

Outro ponto diferente apontado pelo jus filósofo está em que o Garantismo, embora tenha o condão de juridicidade, traz consigo, ao lado dos aspectos formais, os aspectos substanciais, o que até então estava alijado do processo de avaliação jurídica. Eis um contraponto importante à teoria desenvolvida por Hans Kelsen, para o qual se deve abstrair dos valores.

Em Ferrajoli encontram-se os pressupostos formais e substanciais presentes na validação do processo de construção da norma jurídica, porque configura maior grau de legitimidade a esta. Não basta só que uma norma seja elaborada e esteja de acordo com os procedimentos formais alinhados previamente pelo ordenamento jurídico. Isso é o que reflete a Teoria Pura do Direito, de Hans Kelsen.

Na teoria kelseniana, a validação de uma norma é encontrada em outra norma hierarquicamente su- perior e temporalmente anterior. Deveria a novel legislação estar concorde com as balizas formalizadas pela lei superior pretérita. É um sistema de derivação contínua, na qual a posterior valida a anterior. Como já se disse, não se busca a justeza da norma jurídica, mas tão somente se era o direito posto (lei) e se advinda daqueles que poderiam produzi-la, ou seja, da autoridade competente, à qual era dado o poder de competência normativa para criar essa expressão de vontade geral.

É nesse ponto que Luigi Ferrajoli acrescenta o plus da sua teoria, o valor, a materialidade e a substancialidade. Não importa só se a norma obedece aos aspectos formais exigíveis até então. É preciso que ela tenha um valor em si e respeite os valores que compõem o ordenamento jurídico vigente. Eis que, desta forma, haverá solo fértil para o Garantismo Penal, pois não basta ser lei oriunda do processo legislativo, mas, ser lei substancialmente atinente aos valores defendidos e consagrados no sistema constitucional vigente.

Enquadramento formal é pouco, deve-se ter o embasamento substancial, essencial como pressuposto de validação.

Mas Ferrajoli acrescenta um novo elemento ao conceito de validade. Para ele, uma norma será válida não apenas pelo seu enquadramento formal às normas do ordenamento jurídico que lhe são anteriores e configuram um pressuposto para a sua verificação. Supera-se o modelo formalista e vai-se ao encontro do elemento substancial do universo jurídico.

Daí porque se chama a Teoria do Garantismo Penal de um modelo normativo do direito no qual há um sistema de limites à autoridade punitiva com o fito de conferir maior garantia de liberdade ao indivíduo. Não se constitui em um só ato, em um só diploma legal, mas numa ideia que deve ser adotada pelo Estado em todo o seu ordenamento jurídico, principalmente o 
constitucional. É, em resumo, uma garantia jurídica para se asseverar a responsabilidade e a aplicação da pena.

Aqui, a lei inferior é válida quando formalmente realizada, emitida por poder competente, em procedimento previsto, e, máxime, quando não violou a Constituição Federal substancialmente, essencialmente. Não se viola uma lei superior só na sua forma, mas também na sua essência.

Outro ponto de destaque está em que, ao contrário do que apregoou Beccaria para justificar o direito soberano de punir os delitos "na necessidade de defender o depósito da salvação pública das usurpações particulares", Ferrajoli propõe o cognitivismo processual para garantir a verificação da verdade, da forma mais justa e segura em relação ao processo, na busca da verdade (sempre relativa) e afastamento ao máximo do erro (imanente à atividade humana).

Disso se deflui que quanto maior a vontade do Estado em praticar o processo de conhecimento, menor será o de estigmatizar, de punir por punir, pois este exercitará as garantias penais ao máximo e reduzirá as chances de erro, fazendo acontecer a verdadeira justiça, através do devido processo penal de mínima incidência e máximas garantias, pois o processo penal não é um meio de pura repressão, mas de acertamento de fato determinado como crime e de sua autoria.

Nesta esteira, pode-se dizer com Warat (1982, p.48), que a teoria do delito fornece o limite das interpretações legitimáveis. Sem a teoria do delito [...] não se pode expressar uma plenitude significativa para nenhum delito, eis que as normas jurídicas não têm, por si só, um sentido pleno.

Desta forma, a produção de uma ideologia legitimadora do poder punitivo, baseada no Garantismo, acompanha, desde o começo, a história do Direito penal moderno, de acordo com Baratta (1986, p. 79-80 e 82), no marco de um projeto do "Direito Penal".
Cumpre dizer que a composição (modernidade, razão penal, constituição e arbítrio) traz um mapeamento filosófico com fundamentos circundantes no aspecto do Garantismo ou não do direito penal. A modernidade trouxe consigo ideais de progresso, trouxe importantes valores de inspiração humanística. Em seu bojo foram construídos elementos determinantes formados ao longo de sua tradição (Revolução Francesa, quebra do absolutismo, ideias iluministas, ascensão da ciência, declarações de direitos, formação do Estado, ascensão da burguesia, expansão do liberalismo econômico, controle democrático do despotismo político, consolidação do positivismo jurídico) que influenciou as sociedades que sucedeu a este marco histórico, como também trouxe profundas repercussões no mundo do direito em geral, precipuamente do direito penal.

O Direito Penal moderno consubstanciou uma promessa de racionalização do poder punitivo do Estado como garantia dos direitos individuais do acusado. $\mathrm{Na}$ verdade, uma promessa de segurança jurídica, como uma concepção garantidora (cujo ingrediente fundamental é a dicotomia Poder do Estado em face do indivíduo).

Diante do exposto, utilizando-se da inteligência do doutor e professor Carlos Alberto Menezes ${ }^{3}$, conclui-se que a experiência jurídica mostra-se desapontada com a promessa de segurança jurídica que um dia a razão penal prometeu ao indivíduo, dotado de razão e subjetividade, cuja razão moderna contempla-o como aquele que fez a passagem da dependência para a emancipação, tornando-se capaz de responsabilidades (direitos e deveres). Reconhece-se, então, o caráter limitado do sistema penal que apresenta legitimidade com esteio na garantia da legalidade.

3 Possui doutorado em Direito pela Pontifícia Universidade Católica de São Paulo (2008). Atualmente é professor adjunto III da Universidade Federal de Sergipe. Tem experiência na área de Direito, com ênfase em Direito Penal. Professor da Pós-graduação stricto sensu da UFS. 
Em última análise, o Direito Penal passou por diversas transformações e será passível de outras, conforme o acompanhamento histórico da evolução social. Não seria plausível abolir o Direito penal, nem abolir as prisões. Entretanto, deve-se garantir a sua utilização mínima, com base na legalidade e demais garantias acobertadas pela Carta Magna de 1988. De- ve-se ainda promover um profundo debate que envolva não somente os que fazem e aplicam as leis, mas a sociedade como um todo, como receptora de todo o sistema que envolve o ordenamento jurídico, no sentido de assegurar aos cidadãos uma razoável garantia jurídica que afaste os mesmos de qualquer tipo de arbítrio por parte do Estado.

\section{REFERÊNCIAS}

ACHENBACH, Hans. Imputación individual, responsabilidad culpabilidad. In SCHÜNEMANN, Bernd (Comp.). El sistema modern del derecho penal: cuestiones fundamentales: estudios en honor de Claus Roxin en $\mathbf{5 0}^{\circ}$ aniversario. Traducción de Jesús-María Silva Sánchez. Madrid: Tecnos, 1991.

ARISTÓTELES. A Política. Brasília: Editora UnB, 1985.

ARISTÓTELES. Ética a Nicômaco. Tradução de Mário da Gama Kury. Brasília: Editora UnB, 1985.

BARATTA, Alessandro. Viejas y nuevas estrategias en la legitimación del derecho penal. Poder y Control, Barcelona, n.0, p.77-92, 1986.

BARCELLOS, Ana Paula. Neoconstitucionalismo, direitos fundamentais e controle das políticas públicas. Disponível em <http://www.direitopublico. com.br/pdf_seguro/artigo_controle_pol_ticas_p_blicas_.pdf>, acessado em 09.06.2011.

BARROSO, Luís Roberto. Curso de Direito Constitucional Contemporâneo: os conceitos e fundamentais e a construção do novo modelo. $1^{\mathrm{a}}$ ed. São Paulo: Saraiva, 2009.

BATISTA, Nilo. Introdução crítica ao direito penal brasileiro. 8. ed. Rio de Janeiro: Revan, 2002.

BECCARIA, Cesare. Dos delitos e das penas. Tradução de José Cretella Júnior e Agnes Cretella. São Paulo: Revista dos Tribunais, 1999.

BITENCOURT, Cezar Roberto. Falência da pena de prisão: causas e alternativas. 3. ed. São Paulo: Saraiva, 2004.

BITENCOURT, Cezar Roberto. Tratado de direito penal: parte geral. São Paulo: Saraiva, 2003.

BOBBIO, Norberto. 0 positivismo jurídico: Lições de filosofia do direito. Trad. Márcio Pugliesi, Edson Bini e Carlos E. Rodrigues. São Paulo: Ícone, 2006. 
BRASIL. Constituição Federal Brasileira. 33. ed. São Paulo: Saraiva, 2004.

BRASIL. Código Penal. 46. ed. São Paulo: Saraiva, 2008.

BRASIL. Lei de Execução Penal. 44. ed. São Paulo: Saraiva, 2006.

CARVALHO FILHO, José dos Santos. Manual de direito administrativo. São Paulo: Atlas, 2012.

CARVALHO, Salo de. Reincidência e antecedentes criminais: abordagem crítica desde o marco garantista. In: Revista da Ajuris. Porto Alegre: Associação dos Juízes do Rio Grande do Sul, 1999. V. 76.

CARVALHO, Salo. Crítica a execução penal. Rio de Janeiro: Lumem Júris, 2002.

CUNHA JÚNIOR, Dirley. Curso de Direito Constitucional. 5a ed. rev. amp. atual. Bahia: JusPodium, 2011.

FERRAJOLI, Luigi. Direito e razão: teoria do garantismo penal. Trad. Ana Paula Zomer Sica, Fauzi Hassan Choukr, Juarez Tavares e Luiz Flávio Gomes. São Paulo: Revista dos Tribunais, 2002.

FOUCAULT, Michel. Vigiar e punir: nascimento da prisão. Trad. de Raquel Ramalhete. 28. ed. São Paulo: Vozes, 2004.

GIDDENS, Anthony . As consequências da modernidade. Tradução de Raul Fiker. SãoPaulo: Unesp, 1991

GILISSEN, John. Introdução histórica ao direito. 3. ed. Lisboa: Fundação Calouste Gulbenkian, 2001.

HABERMAS, Jürgen. 0 Discurso Filosófico da Modernidade: doze lições; tradução Luiz Sérgio Repa, Rodnei Nascimento. São Paulo: Martins Fontes, 2000.

HEGEL, Georg. Princípios da Filosofia do Direito. Trad. Orlando Vitorino, São Paulo: Martins Fontes, 2000.

HOBBES, Thomas. 0 Leviatã. São Paulo: Ed. Martin Claret, 2006.

KANT, Immanuel. Ideia de uma História Universal de um Ponto de Vista Cosmopolita. São Paulo: Martins Fontes, 2003.

LOWY, Michael. Ideologias e ciência social - elementos para uma análise marxista. 1996, p. 40: "O positivismo, que se apresenta como ciência livre de juízos de valor, neutra, rigorosamente científica, (...) acaba tendo uma função política e ideológica”. 
LUISI, Luiz. Os princípios constitucionais penais. 2. ed. Porto Alegre: Sergio Antonio Fabris, 2003.

MENEZES, Carlos Alberto. 0 limite das exculpantes penais: a inexigibilidade de conduta diversa como topos e solução. Tese Doutorado. São Paulo: USP, 2008.199 p.

MIRABETE, Júlio Fabbrini. Execução penal. 11. ed. São Paulo: Atlas, 2004.

MORAES, Alexandre de. Direito constitucional. 13. ed. São Paulo: Atlas, 2003.

MONTESQUIEU. Do espírito das leis. Rio de Janeiro: Ediouro, 1991.

PRADO, Luiz Regis. Curso de direito penal brasileiro: parte geral. São Paulo: Revista dos Tribunais, 2005.

REALE JÚNIOR, Miguel. Instituições de direito penal: parte geral. 3. ed. Rio de Janeiro: Forense, 2009, v. 1. $540 \mathrm{p}$.

ROUSSEAU, Jean-Jacques. Do Contrato Social. Trad. Pietro Nassetti, São Paulo: Editora Martin Claret, 2006.

SILVA, José Afonso. Comentário contextual à Constituição. São Paulo: Malheiros, 2005.

WARAT, Luis Alberto. Mitos e teorias na interpretação da lei. Porto Alegre: Síntese, 1982.

ZAFFARONI, Eugenio Raúl. PIERANGELI, José Enrique. Manual de direito penal brasileiro: parte geral. 5. ed. rev. e atual. São Paulo: Revista dos Tribunais, 2004. 